hydrocarbons. Clear indications of migration of larger extent were not observed neither in or near the Myalina Limestone outcrops.

The locality at Nathorst Fjord was partly covered by snow which prevented the detailed investigation regarding possible migration phenomena. It was observed however that cyclic sedimentation appears to have been important during the deposition of the Myalina Limestone. Variations in composition and thickness of the Myalina Limestone and its bituminous intercalations were noted. A sample collected previously from this locality has been determined to be a good source rock, whereas samples from other localities produced negative results by earlier analysis.

N. B. H.S., Olexcon International $N . V$., The Hague, Netherlands.

K.P-N., Institut for historisk Geologi og Palceontologi, University of Copenhagen, $\emptyset$ stervoldgade 10 , 1350 Copenhagen $K$.

\title{
PROCESSING AND INTERPRETATION OF RADIOMETRIC FLIGHT DATA FROM CENTRAL EAST GREENLAND
}

\section{Leif Løvborg and Bjarne Leth Nielsen}

The data obtained from the aeroradiometric survey carried out by GGU in 1971 in the Scoresby Sund region (Nielsen, 1972), have been digitised and stored on magnetic tape in order to permit a processing on the Burroughs B-6700 computer housed at the Danish Atomic Energy Commission's Research Establishment at Ris $\varnothing$. This note describes the method of processing these data, leading to an interpretation and correlation with the bedrock geology of a selected area.

\section{Processing of data}

The strip-chart records produced by the four-channel airborne gamma spectrometer and the radar altimeter were traced with India ink on $36 \mathrm{~cm}$ wide sheets of transparent paper. Next, the five curves on each sheet were successively digitised in the form of punched paper tape using an optical curve follower controlled by the Ris $\varnothing$ EAI-680/PDP-8 hybrid computer. Finally, all punched-tape information was directly transferred to magnetic tape on the B-6700 computer.

The data processing began with a recovery of gamma spectrometer count-rates and flying altitudes, expressed in units of counts per second and feet respectively. Cards were punched describing the various positions of the ratemeter range selectors in the course of the survey, and these cards served as input to a special computer programme which converted the data on the magnetic tape into true 


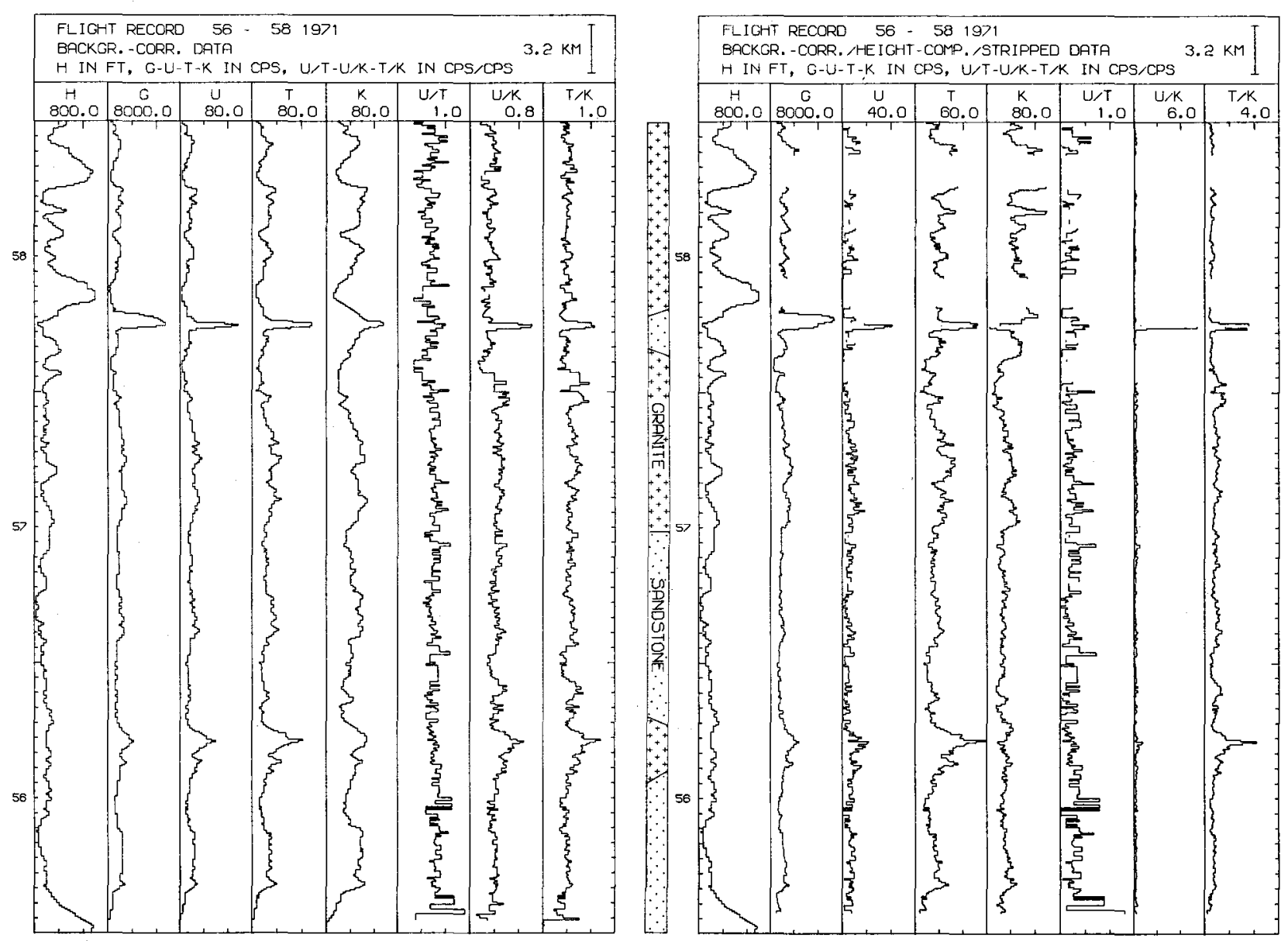

Fig. 6. Radiometric flight line, and geological section for comparison, of a part of south-eastern Milne Land, East Greenland. To the left the profile has been only corrected for background, to the right it has been corrected for both background and height. Full explanation is given in the article by Løvborg \& Nielsen. 
units of measurement. Next, the flight data were gradually presented in the form of computer-generated plots, each representing the radiometric profile along the corresponding flight path. A total of eight curves were drawn on the $25 \mathrm{~cm}$ wide paper chart of the Calcomb plotter. These showed the variations of the flying altitude $\mathrm{H}$, the gross gamma-ray count-rate $\mathrm{G}$, the count-rates $\mathrm{U}, \mathrm{T}$ and $\mathrm{K}$ in the uranium, thorium and potassium counting channels, and the ratios $U / T$, $\mathrm{U} / \mathrm{K}$ and $\mathrm{T} / \mathrm{K}$. The computer programme written for this purpose has options which permit the count-rate data to be corrected for background, terrain clearance (height) and interdependence of the signals from the $\mathrm{U}, \mathrm{T}$ and $\mathrm{K}$ counting channels (stripping). The terrain clearance correction was generally found to have a disturbing effect on data recorded over areas of rugged topography and this correction therefore often was omitted.

\section{Results and interpretation}

Two resulting plots from south-eastern Milne Land (see fig. 5) are given in figure 6. These have been chosen as an example of the interpretation of the flight data demonstrating the correlation between the plotted curves and the geological information from the field and laboratory. One of the plots has been corrected only for the background radiation, whereas in the second plot the data have been stripped and corrected for background and height.

The flight data were recorded at Milne Land where Upper Jurassic Charcot Bugt Sandstone rests upon Caledonian crystalline rocks (see Håkansson et al., 1971). In places the irregular pre-Jurassic basement surface has protected the Charcot Bugt Sandstone from erosion and remnants of the sandstone have been preserved. Also, windows of crystalline rocks occur in the Charcot Bugt Sandstone.

The plots show an enriched radioactivity spatially distributed along the contacts between the crystalline rocks and the sandstone. Field investigations have confirmed that radioactive heavy minerals were formed as placer deposits along the contact zone. The geological sketch column along the plots (see fig. 6) shows a crystalline window at $\mathbf{A}$ and a sandstone remnant at $\mathbf{B}$. The general change in radioelement content between the main areas of Charcot Bugt Sandstone and basement is distinctively demonstrated in the corrected plot. The more intensive mineralisation at A and B can be seen in both plots, and it is furthermore obvious that the anomalies are combined $\mathrm{Th}$ and $\mathrm{U}$ mineralisations as supported by the uniform $U / T h$ values. The $K$ peak in the uncorrected plot has, due to an insufficient spectrum correction, been turned into a low in the corrected plot. This effect is clearly seen in the corrected plots of the ratios $U / K$ and $T / K$.

The different levels of the recorded radiation (corrected plots) are in good agreement with laboratory gamma-spectrometric determinations of $\mathrm{U}$, Th and $\mathrm{K}$ contents (see table 1).

It should finally be noted how the plots of the ratios $U / T, U / K$ and $T / K$ show 
Table 1. Gamma-spectrometric assays of radioactive elements in hand samples compared with c. p. s. levels from the airborne survey

\begin{tabular}{lcccccc}
\hline Rock type & $\mathrm{U}(\mathrm{ppm})$ & $\mathrm{Th}(\mathrm{ppm})$ & $\mathrm{K}(\%)$ & $\mathrm{U}$ (c.p.s.) & T (c.p.s.) & $\mathrm{K}$ (c.p.s.) \\
\hline $\begin{array}{c}\text { Charcot Bugt Sandstone, } \\
\text { not mineralised } \\
(1 \text { sample })\end{array}$ & 0.84 & 6.28 & 1.02 & $5-10$ & c. 25 & c. 30 \\
\hline $\begin{array}{c}\text { Charcot Bugt Sandstone, } \\
\text { mineralised } \\
\quad(10 \text { samples })\end{array}$ & 160 & 627 & 1.61 & $20-40$ & $70-90$ & c. 30 \\
\hline $\begin{array}{c}\text { Granitic basement } \\
(3 \text { samples })\end{array}$ & 1.65 & 8.22 & 2.42 & c. 10 & $25-30$ & $40-50$ \\
\hline
\end{tabular}

apparent drastic changes along the flight line compared to the apparently smoother changes in the plots of the element activities. This is explained by an insufficient statistical significance of the count rates in the $\mathrm{U}, \mathrm{T}$ and $\mathrm{K}$ channels, exaggerated when the ratios are calculated.

\section{References}

Håkansson, E., Birkelund, T., Heinberg, C. \& Willumsen, P. 1971: Preliminary results of mapping the Upper Jurassic and Lower Cretaceous sediments of Milne Land. Rapp. Grønlands geol. Unders. 37, 32-41.

Nielsen, B. L. 1972: Aeroradiometric survey in the Scoresby Sund region, East Greenland. Rapp. Grønlands geol. Unders. 45, 42-43.

L. L.,

Danish Atomic Energy Commission,

Research Establishment Risø,

4000 Roskilde.

\section{GENERAL COMPILATION OF ISOTOPIC WORK ON ROCKS FROM GREENLAND}

\section{Compiled by David Bridgwater}

1972 has seen a further development of the trend noted in Report of Activities, 1971 towards detailed isotopic studies of particular petrological and geochronological problems rather than the regional programmes of $\mathrm{K} / \mathrm{Ar}$ mineral age determinations carried out previously. As the main picture of Greenland geochronology emerges so the problems to be solved become more complex and require close 